УДК 349.3

DOI https://doi.org/10.32849/2663-5313/2020.4.18

\title{
Альона Бурка,
}

асистент кафедри приватного права

юридичного факультету

Чернівецького начіонального університету імені Юрія Федъковича

\section{ДЕРЖАВНА ДОПОМОГА ПРИ НАРОДЖЕННІ ДИТИНИ: ПРОБЛЕМНІ АСПЕКТИ}

Одним із видів сочіального забезпечення сімей з дітьми є допомога при народженні дитини як різновид державної допомоги. У статті здійснено ретроспективний аналіз окремих норм права, що регулюють розміри та підстави припинення допомоги при народженні дитини; аналіз судової практики, в тому числі практики Верховного Суду, Конституиійного Суду, визначено проблемні аспекти під час реалізаиї особами права на отримання допомоги при народженні дитини.

Автор зазначає, що на основі аналізу судової практики вдалося визначити таке: основною підставою для звернення до суду здебільшого є відмова у виплаті допомоги у зв'язку із пропуском строків для звернення за ї призначенням. У разі пропуску строку для звернення з поважних, об'єктивних причин мало місие задоволення позову і призначення допомоги, насамперед виходячи із інтересів дитини. Якщо ж пропуск строку відбувався з неповажни причин чи не підтверджено їх значущість, об'єктивний характер - позов не підлягав задоволенню.

Здійснено аналіз окремих рішень Конституиійного Суду про визнання неконституційними положень щодо підстав припинення виплати допомоги та визнання конституиійними положень щодо зменшення розміру допомоги при народженні дитини у зв'язку із фінансово-економічним становищем держави. Зроблено висновок щодо певної абсурдності позииї Конституиійного Суду.

Автор зауважує, що розмір державної допомоги при народженні дитини є одним із основних факторів, який впливає на рівень народжуваності в Украӥні. $Е$ необхідність більш детально врегулювати питання щодо иільового використання коштів, які виділяються на потреби дітей, для того щоб запобігати випадкам їх неналежного використання. У статті запропоновано встановити, що у разі пропуску звернення за призначенням допомоги з поважних причин заявникам повинен надаватися додатковий строк для звернення, не менше двох місяиів.

Ключові слова: соціальне забезпечення, матеріальне забезпечення, розмір допомоги, цільове використання коштів.

Постановка проблеми. Система соціальної підтримки сімей із дітьми виступає одним із інститутів реалізації соціальноекономічної політики, мета якої полягає у забезпеченні соціальної стабільності і розвитку суспільства [1, с. 228]. Одним із видів соціального забезпечення сімей із дітьми $є$ надання державної соціальної допомоги, основне призначення якої полягає у разовій або тимчасовій матеріальній підтримці. Ефективний соціальний захист сімей 3 дітьми є найважливішою умовою подолання дитячої бідності, забезпечення рівних прав і можливостей для розвитку всіх дітей незалежно від походження i майнового стану їхніх батьків. Натепер стан соціальної підтримки сімей з дітьми в Україні оцінюється досить негативно, оскільки чинна система допомоги має на меті лише часткове подолання соціальних ризиків у цій сфері, ускладнюе ситуацію і наявність прогалин у праві, що призводить до неоднакового застосування правових норм, зменшення розміру допомоги тощо.

Аналіз останніх досліджень та публікацій. Питання правової природи, видів та значення державної допомоги загалом та державної соціальної допомоги при народженні дитини зокрема досліджували О. Г. Азарова, Н. Б. Болотіна, Т. С. Гусева, Ю. Б. Корсаненкова, Л. В. Кулачок, С. С. Лукаш, П. Д. Пилипенко, I. М. Сирота, Л. В. Стрепко, В. С. Тарасенко, С. П. Яригіна, О. М. Ярошенко, проте сьогодні виникає необхідність розглянути на основі аналізу судової практики більш детально, 3 якими проблемами можна стикнутися у процесі реалізації права на отримання допомоги при народженні дитини, а також здійснити детальний аналіз окремих норм права, що визначають порядок виплати і розміри допомоги. 
Метою статті є ретроспективний правовий аналіз судової практики, норм права, що регулюють відносини з приводу порядку отримання та розміру державної допомоги при народженні дитини.

Виклад основного матеріалу. Основними нормативно-правовими актами, що регулюють порядок надання допомоги при народженні дитини, є Закон України «Про державну допомогу сім'ям 3 дітьми» від 21 листопада 1992 року [2] та Постанова КМУ від 27 грудня 2001 року № 1751 «Про затвердження Порядку призначення і виплати державної допомоги сім'ям з дітьми» [3].

Відповідно до Закону України «Про державну допомогу сім'ям $з$ дітьми», допомога при народженні дитини надається за рахунок коштів Державного бюджету України. Право на отримання даного виду допомоги мають один із батьків дитини, опікун, які постійно проживають разом 3 дитиною. У разі народження (встановлення опіки) двох і більше дітей допомога надається на кожну дитину. Допомога не призначається, якщо дитина народилася мертвою.

Однією із основних умов отримання допомоги є своєчасне звернення за їі призначенням, а саме не пізніше дванадцяти місяців 3 дня народження дитини. На практиці пропуск строку звернення i, як наслідок, відмова у призначенні допомоги найчастіше і $є$ підставою для звернення до суду. Нині ця проблема найбільш поширена серед батьків, які проживають на тимчасово окупованій території або були змушені переміститися на підконтрольну територію.

Проаналізувавши ряд судових рішень (судові рішення № 1[4], № 2 [5], № 3[6], № 4 [7], № 5 [8], № 6 [9], № 7 [10]), можна констатувати, що, розглядаючи дану категорію справ, суди виходять із того, що Законом України «Про державну допомогу сім'ям 3 дітьми» та Постановою КМУ № 1751, які регулюють правовідносини щодо виплати грошової допомоги при народжені дитини, не передбачено поновлення строку звернення за її призначенням у разі його пропуску. Проте якщо пропуск строку відбувся з об'єктивних, поважних причин, що не залежали від волі заявника (хвороби дитини, неможливості отримання свідоцтва про народження дитини, внаслідок проведення на сході України бойових дій), що будуть підтверджені належними доказами, то пропуск строку звернення не позбавляє позивача та їі дитину права на отримання допомоги. Якщо ж пропуск строку для звернення відбувся з неповажних причин, внаслідок суб'єктивних дій позивача, то позов не підлягав задоволенню.
До аналогічних висновків дійшов і Верховний Суд (Постанова Верховного суду від 14 лютого 2018 року К/9901/12622/18 [11] та Постанова Верховного суду від 02 жовтня 2018 року справа № 495/3711/17 [12]). Окрім цього, Верховний Суд наголошує на тому, що допомога при народженні дитини за своєю природою є допомогою самій дитині, а не її батькам. А тому неможливість своєчасного звернення одним із батьків до органу, який здійснює призначення допомоги при народженні дитини, призводить до порушення інтересів дитини.

Під час розгляду таких судових справ насамперед враховуються інтереси дитини відповідно до п. 1 ст. 3 Конвенції про права дитини від 20 листопада 1989 року (в редакції зі змінами, схваленими резолюцією 50/155 Генеральної Асамблеї ООН від 21 грудня 1995 року); положення статті 13 Конвенції про захист прав людини і основоположних свобод (право на ефективний засіб юридичного захисту).

Розмір допомоги при народженні дитини не $є$ сталим та періодично змінюється. До 2014 року допомога при народженні дитини була диференційованою та залежала від кількості дітей і розміру прожиткового мінімуму. Після 30 червня 2014 року допомога при народженні дитини призначається у розмірі 41280 гривень (одноразова виплата здійснюється у сумі 10320 гривень, решта допомоги виплачується протягом наступних 36 місяців рівними частинами).

До 30 червня 2014 року у статті 12 Закону України «Про державну допомогу сім'ям 3 дітьми» передбачалося, що допомога при народженні дитини нараховується виходячи 3 розміру прожиткового мінімуму для дітей віком до шести років, установленого на день народження дитини, та надавалася у сумі, кратній 30 розмірам прожиткового мінімуму, - на першу дитину; кратній 60 розмірам прожиткового мінімуму, - на другу дитину; кратній 120 розмірам прожиткового мінімуму, - на третю і кожну наступну дитину. Якщо врахувати те, що з 01 січня 2020 року розмір прожиткового мінімуму становить 2027 грн [13], то розміри допомоги при народженні дитини могли би бути такими: 60810 тис. грн. - на першу дитину; 121620 тис. грн - на другу дитину; 243240 тис. грн - на третю дитину.

Рішенням Конституційного Суду від 7 листопада 2018 року № 9-р/2018 (Справа № 1-3/2018(2717/14) було встановлено, що внесення змін до Закону України «Про державну допомогу сім'ям з дітьми» від 21 листопада 1992 року № 2811-XII зі змінами, Законом України «Про запобігання фінансової 
катастрофи та створення передумов для економічного зростання в Україні», прийнятим Верховною Радою України 27 березня 2014 року за № 1166 -VII, зокрема: «2) текст статті 12 викласти у такій редакції: «Допомога при народженні дитини призначається у розмірі 41280 гривень. Виплата допомоги здійснюється одноразово у сумі 10320 гривень, решта суми допомоги виплачується протягом наступних 36 місяців рівними частинами у порядку, встановленому Кабінетом Міністрів України»-відповідають Конституції України [14].

Ухвалюючи таке рішення, Конституційний Суд виходив із того, що фінансування соціальних та інших зобов'язань держави має бути реальним та здійснюватися відповідно до іï фінансово-економічних можливостей. У разі значного погіршення фінансово-економічної ситуації, виникнення умов воєнного або надзвичайного стану, необхідності забезпечення національної безпеки України, модернізації системи соціального захисту тощо держава може здійснити відповідний перерозподіл своїх видатків з метою збереження справедливого балансу між інтересами особи та суспільства. Проте держава не може вдаватися до обмежень, що порушують сутність конституційних соціальних прав осіб, яка безпосередньо пов'язана з обов'язком держави за будь-яких обставин забезпечувати достатні умови життя, сумісні з людською гідністю.

На тому, що наявні ресурси держави та її соціальні зобов'язання є взаємозалежними, наголошено і в актах міжнародного права з питань захисту прав і свобод людини і громадянина (стаття 22 Загальної декларації прав людини від 1948 року; пункт 1 статті 2 Міжнародного пакту про економічні, соціальні і культурні права 1966 року).

Відповідно до положень частини третьої статті 22 Конституції України під час прийняття нових законів або внесення змін до чинних законів не допускається звуження змісту та обсягу наявних прав і свобод.

Конституційний Суд України вважає, що оскільки допомога при народженні дитини, допомога по догляду за дитиною до досягнення нею трирічного віку та допомога при усиновленні дитини встановлені законом і конкретно не визначені в Конституції України як складники права на соціальний захист, гарантованого іiі статтею 46, то Верховна Рада України має свободу дій щодо законодавчого регулювання порядку надання цих видів державної допомоги і на них не поширюються й визначені їі статтею 22 гарантії щодо заборони скасування чи звуження змісту та обсягу прав.
Оспорювані положення ухвалені з метою реалізації заходів щодо економного та раціонального використання державних коштів, недопущення втрат Державного бюджету України, забезпечення соціальної підтримки громадян виходячи з фінансових можливостей держави.

Як бачимо, основним аргументом Конституційного Суду є те, що такий різновид соціального забезпечення, як державна допомога при народженні дитини, безпосередньо не передбачений у статті 46 Конституції України, на відміну від пенсій. Вважаємо, що таке обгрунтування має елементи абсурдності, оскільки, по-перше, всі види соціального забезпечення апріорі не можуть бути закріпленні у Конституції України; по-друге, допомога при народженні дитини, як й інші види соціального забезпечення, підпадають під категорію «інші види соціальних виплат та допомог»; по-трете, таке обгрунтування означає, що лише розміри пенсійних виплат не можуть бути зменшенні при прийнятті нових законів, а всі інші - можуть, виходячи із фінансово-економічних можливостей країни.

Виплата допомоги при народженні дитини припиняється у разі: позбавлення отримувача допомоги батьківських прав; відібрання дитини в отримувача допомоги без позбавлення батьківських прав; тимчасового влаштування дитини на повне державне утримання; припинення опіки або звільнення опікуна від його повноважень щодо конкретної дитини; нецільового використання коштів і незабезпечення отримувачем допомоги належних умов для повноцінного утримання та виховання дитини.

У частині дев'ятій статті 11 Закону України «Про державну допомогу сім'ям 3 дітьми» (у редакції закону від 01 січня 2016 року) передбачалося, що виплата допомоги при народженні дитини припиняється $\mathrm{i} \ll \mathrm{y}$ разі виникнення інших обставин». Проте рішенням Конституційного суду від 8 червня 2016 року № 3-рп/2016 у справі № 1-2/2016 дане положення було визнано неконституційним [15].

За правовою позицією Конституційного Суду України, викладеною у рішенні від 22 вересня 2005 року № 5-рп/2005, із конституційних принципів рівності і справедливості випливає вимога визначеності, ясності і недвозначності правової норми, оскільки інше не може забезпечити її однакове застосування, не виключає необмеженості трактування у правозастосовній практиці і неминуче призводить до сваволі [16]

Аналіз змісту частини дев'ятої статті 11 Закону вказує на те, що законодавець передбачив таку підставу для припинення виплати 
допомоги при народженні дитини, як «виникнення інших обставин», не закріпивши критеріїв їх визначення. Таким чином, абзац сьомий частини дев'ятої статті 11 Закону, у якому передбачено припинення виплати допомоги при народженні дитини «у разі виникнення інших обставин», є таким, що суперечить частині першій статті 8 Конституції України.

У даному випадку повністю підтримуємо позицію Конституційного Суду, оскільки, як свідчить практика, відсутність чіткості та конкретики у нормі права призводить до її застосування «на власний розсуд» і, як правило, до порушень прав осіб.

Окрім цього, на рівні закону передбачений контроль за цільовим використанням державної допомоги, що повинен здійснюватися працівниками центрів соціальних служб для сім'ї, дітей та молоді або уповноваженою особою, визначеною виконавчим органом ради об'єднаної територіальної громади, в межах повноважень. У разі встановлення факту нецільового використання коштів зазначені органи подають керівнику органу, що призначив допомогу, пропозиції щодо припинення її виплати.

На жаль, в Україні відсутній ретельний контроль за використанням дитячих коштів, що досить часто призводить до їх витрачання не на потреби дітей. Для того, щоб змінити ситуацію, насамперед має бути визначений хоча би примірний перелік дій, які вважатимуться «цільовим використанням коштів», деталізувати процедуру, як саме і з якою періодичністю буде здійснюватися перевірка використання коштів, можливо, для цього краще, щоб кошти зберігалися на спеціальному соціальному рахунку.

\section{Висновки}

Дослідивши окремі нормативно-практичні аспекти отримання допомоги при народженні дитини, можна зробити такі висновки:

1) розмір допомоги при народженні дитини є одним із факторів, що впливає на народжуваність в Україні, зменшення у 2014 році його розміру можна розцінювати як порушення прав дитини, проте за рішенням Конституційного Суду такі зміни були конституційними;

2) вважаємо, що розмір допомоги при народженні дитини, як і більшість видів виплат, повинен щороку переглядатися з урахуванням інфляційних процесів. Адже $€$ велика різниця між тим, що можна було придбати для дитини на суму 41280 грн. у 2014 році та у 2020 році. Для цього доречно розмір допомоги визначати не у фіксованій сумі, а, наприклад, як це було до 2014 року, у прожиткових мінімумах, які щороку змінюються (у бік збільшення);

3) потребує детального врегулювання питання «цільового використання коштів», для того щоб вони витрачалися виключно для задоволення потреб та інтересів дитини;

4) на рівні закону не передбачено можливості поновлення чи продовження строку для звернення за призначенням допомоги у разі його пропуску з поважних причин. Вважаємо, що у разі підтвердження особою факту пропуску строків з незалежних від неї обставин потрібно надавати додатковий строк для звернення - не менше двох місяців.

\section{Список використаних джерел:}

1. Стинська В. Соціальна підтримка материнства й дитинства в Бельгії. Людинознавчі студї. Серія «Педагогіка». 2016. Випуск 2/34. С. 228-235.

2. Про державну допомогу сім'ям 3 дітьми : Закон України від 21 листопада 1992 року № 2811-XII / Верховна Рада України. URL: https:// zakon.rada.gov.ua/laws/show/2811-12 (дата звернення: 15.03.2020).

3. Про затвердження Порядку призначення і виплати державної допомоги сім'ям 3 дітьми : Постанова КМУ від 27 грудня 2001 року № 1751 // База даних «Законодавство Українu». URL: https://zakon.rada.gov.ua/laws/show/ 1751-2001-\%D0\%BF (дата звернення: 20.03.2020).

4. Рішення Херсонського окружного адміністративного суду від 05 березня 2018 року у справі № 653/171/18 // База даних «Є диний державний реєстр судових рішень». URL: http:// www.reyestr.court.gov.ua/Review/72595315 (дата звернення: 19.03.2020).

5. Рішення Миколаївського окружного адміністративного суду від 29 травня 2019 року у справі № 400/1173/19 // База даних «Є диний державний реєстр судових рішень». URL: http:// www.reyestr.court.gov.ua/Review/82075191 (дата звернення: 15.03.2020).

6. Рішення Луганського окружного адміністративного суду від 29 жовтня 2018 року у справі № 1240/2832/18 // База даних «Сдиний державний реєстр судових рішень». URL: http:// www.reyestr.court.gov.ua/Review/77469052 (дата звернення: 15.03.2020).

7. Рішення Одеського окружного адміністративного суду від 05 листопада 2019 року у справі № 420/5191/19 // База даних «Є диний державний реєстр судових рішень». URL: http:// www.reyestr.court.gov.ua/Review/85498530 (дата звернення: 17.03.2020).

8. Рішення Харківського окружного адміністративного суду від 29 жовтня 2019 року у справі № 645/5248/19 // База даних «Єдиний державний реєстр судових рішень». URL: http:// www.reyestr.court.gov.ua/Review/85266445 (дата звернення: 18.03.2020). 
9. Рішення Донецького окружного адміністративного суду від 05 вересня 2019 року у справі №200/8245/19-а // База даних «Єдиний державний реєстр судових рішень». URL: http:// www.reyestr.court.gov.ua/Review/84069565 (дата звернення: 19.03.2020).

10. Рішення Київського окружного адміністративного суду від 18 листопада 2019 року у справі № 320/3194/19 // База даних «Єдиний державний реєстр судових рішень». URL: http:// www.reyestr.court.gov.ua/Review/85734884 (дата звернення: 19.03.2020).

11. Постанова Верховного Суду від 14 лютого 2018 року К/9901/12622/18 // База даних «Єдиний державний реєстр судових рішень». URL: http://reyestr.court.gov.ua/Review/72289105 (дата звернення: 18.03.2020).

12. Постанова Верховного Суду від 02 жовтня 2018 року у справі № 495/3711/17. База даних «Є диний державний реєстр судових рішень». URL http://reyestr.court.gov.ua/Review/76884600 (дата звернення: 18.03.2020).
13. Про державний бюджет України на 2020 рік : Закон України від 14 листопада 2019 року № 294-IX / Верховна Рада Украӥни. URL: https://zakon.rada.gov.ua/laws/show/294-IX (дата звернення: 23.03.2020).

14. Рішення Конституційного Суду від 7 листопада 2018 року № 9-р/2018 Справа № 1-3/2018(2717/14) // База даних «3аконодавство Украӥни». URL: https://zakon.rada.gov.ua/ laws/show/v009p710-18 (дата звернення: 13.03.2020).

15. Рішення Конституційного суду від 8 червня 2016 року № 3-рп/2016 у справі № 1-2/2016 // База даних «Законодавство Украïнu». URL: https://zakon.rada.gov.ua/laws/show/ v003p710-16 (дата звернення: 11.03.2020).

16. Рішення Конституційного Суду від 22 вересня 2005 року № 5-рп/2005 // База даних «Законодавство України». URL: https:// zakon.rada.gov.ua/laws/show/v005p710-05 (дата звернення: 23.03.2020).

One of the types of social security provisions for families with children is childbirth assistance as a form of governmental assistance. The article provides a retrospective analysis of certain norms of law which regulate the size and the grounds for termination of assistance at birth; analysis of the case law, including the practice of the Supreme Court and the Constitutional Court; and the problematic aspects of the person's right to receive assistance at birth realization are identified.

The author notes that, based on the analysis of the case law, the following can be determined: the main reason for going to the court in most of the cases is the refusal to pay the assistance when the application for the assistance appointment was terminated. When the due date was missed due to the valid, objective reasons, the claim was settled and the assistance provided, primarily in the interests of the child. If, however, the termination of the time limit was due to unreasonable grounds, or in case their validity was not confirmed, then the claim was not the subject to satisfaction.

Some decisions of the Constitutional Court, which relate to the recognition of some of the grounds for the suspension of assistance payment as unconstitutional and some of the thesis regarding the reduction of the amount of childbirth allowance related to the financial and economic situation of the state as constitutional, are analyzed. A conclusion was made regarding the certain absurdity of the position of the Constitutional Court.

The author notes that the amount of state assistance at birth is one of the main factors affecting the birth rate in Ukraine. There is a need to address the issue of the targeted use of the provisions allocated to the needs of children more specifically to prevent them from being misused. The article suggests establishing that in case of the termination of the application for assistance for valid reasons, applicants should be given an additional period for application for at least two months.

Key words: social security, financial aid, amount of assistance, targeted use of funds. 